ISBN - 978-93-86878-38-0
16th TURKEY International Conference on Industry, Law, Education and Interdisciplinary Studies

(TILEIS-20)

Istanbul (Turkey) March 2-4, 2020

\title{
The Political Aspects of Westerners Teaching English in Eastern Countries: A Look at East Asia
}

\author{
Victoria J. Morrison ${ }^{1}$ \\ ${ }^{1}$ Wilkes University, U.S.A.
}

\begin{abstract}
English is the most widely spoken language throughout the world. It is also the leading language for business, with Mandarin as a close second. English was spread throughout the world by western civilization in today's society, and that is very much still the case today. Many teachers or new graduates from western countries and universities set out to become teachers in foreign countries for various reasons, such as the opportunity to travel and find adventure. However, one must also ask, how do the local teachers feel when foreigners come in to teach in their schools? Do they feel that their jobs are being stolen? Do they welcome the challenge or welcome the diversity that comes naturally with the mixing of cultures, or do they resent it? Over the years one thing has become clear: the teaching of English in a foreign country is more than just a linguistic issue. This paper examines the political ramifications of teaching English as a westerner through an examination of policies, practices, and perceptions in three Asian countries
\end{abstract}

Keywords: English, ESL, TESL, teaching English abroad

\section{Introduction}

Teaching English abroad is an attractive job for a young professional who is eager for international cultural exchange. There are several factors that may contribute to the decision to go abroad for such a job. First is the opportunity for building up personal funds. Teaching abroad is a good starting job that, if budgeted correctly, can be a great way to pay off some of the large student debt that burdens many western graduates, particularly from the U.S. (Bentley, 2013). The next reason to teach abroad is the desire to travel (Bentley, 2013). Those who want to travel for minimal cost may become international teachers in order to explore the world and gain new experiences. Third is the advantage that native English speakers have in this field. Schools often choose to hire native English speakers so that the students are immersed in the authentic language learning experience (Bentley, 2013). Plus, having a commonly heard English accent, thanks to the western music and movie industries, is an advantage; hence, teachers from countries such as America, South Africa, and England are often considered to be the most employable of English teachers (English Program in Korea, 2019).

Lastly, English is a valuable commodity in international business. Not only is English the most widely spoken language globally (Pennycook, 2017), it is known that English is the most commonly used language for international business (Griffin \& Pustay, 2015). "English functions as a gatekeeper to positions of prestige in a society" (Pennycook, 2017, p. 14). Since the East Asian countries are often highly involved in and reliant upon international business and trade for the development of their economies' revenues, it only makes sense that English be heavily implemented in their educational systems. Countries such as South Korea, Malaysia, and Japan are especially reliant upon international business within their major export goods from such well-known companies as Samsung, Hyundai, Petronas, and Toyota, among others. 
Even though teaching English abroad as a westerner seems like a dream job to many young professionals, there are still some conflicts included with the profession (Gray, 2003). The Fulbright English for All programs, funded by the U.S. Department of State (Fulbright, 2019), offers many opportunities for teachers of English to experience cultural exchanges worldwide through an English Teaching Assistant (ETA) program, which gives grants for Americans to support, rather than replace, the English teachers in the host country. Programs such as the Fulbright ETA initiative acknowledge the reality that, according to Abdullah and Eng (2017), there are sensitive cultural, social and political issues involved in the teaching of English worldwide. As expressed by Pennycook (2017):

The global spread of English is a bigger problem now than it ever was and we continue to need ways to address this. As Tollefson (2000, p. 8) has warned, 'at a time when English is widely seen as a key to the economic success of nations and the economic well-being of individuals, the spread of English also contributes to significant social, political, and economic inequalities' (p. viii).

Therefore, in order to examine the issue, the most important question is, What are the cross-cultural effects and political ramifications of westerners teaching English in East Asian countries? This question will be discussed through an examination of the policies, perspectives, and practices of three East Asian countries: Malaysia, South Korea, and Japan.

\section{Malaysia}

Westerners teaching English abroad is a complex issue that has political aspects as well. For example, the nationalism movement in Malaysia since gaining independence from Britain in 1957 has fueled the government's efforts to push away from colonialism and reclaim their own cultural heritage hiring foreign teachers is now seen as taking jobs away from locals (Manan, David, Dumanig, \& Naqeebullah, 2015) .

While the Malaysian government is highly supportive of bringing in international teachers to teach English (Thirusanku \& Yunus, 2012; 2014), local teachers are not so supportive, especially in public schools (Manan, David, Dumanig, \& Naqeebullah, 2015). Due to the movement of nationalism over the years, the government made Malay (also called Bahasa Melayu) the native language and English became the second language (Hanapiah, 2004). This meant transitioning all teaching and lessons in public schools from English to Malay in order to comply with the government's educational policies. However, the effects of this movement are seen in the fact that, for at least the last three generations, Malaysian students are struggling with communicating in standard English and finding it hard to continue their studies overseas due to their reduced English based education. To keep up with the times and demands of the world, the current government is attempting to change the school systems back to being English based. This will allow future generations of Malaysians to keep up with the rest of the world.

The problem in Malaysia with changing the system right now is that local teachers do not always have all the skills or the English-speaking level required to make the transfer. This has led to the attempt to implement foreign English teachers into public schools around the country. Western teachers have always been welcomed in the elite international schools, but the problem now is that public school teachers are often against bringing in foreign teachers to teach English because they feel they have the appropriate skills to educate students properly. To help find a compromise, the Fulbright English Teacher Assistant program sends 100 teaching assistants--not professional teachers--over to Malaysia each year (Fulbright, 2019). Currently, in Malaysia there is slight tension between the government and the people regarding the education system. The government is looking to aggressively expand and implement their English based curriculum, whereas local teachers and communities are more reluctant to change the way children are being schooled. They feel that re-implementing English into the education systems would be more of a threat to their unique culture rather than a stepping stone to becoming a fully developed nation (Hanapiah, 2004).

In summary, one of the major questions affecting the situation in Malaysia right now is, What is the current political perspective on foreign teachers teaching English in Malaysia, and how does that perspective 
between the government and the people? The answer to that question is complicated, but the best way to explain it is that the Malaysian Ministry of Education is highly supportive and wants to implement foreign teachers in more schools; however, the people are not generally in favor of the implementation. Now, they are not always against foreign teachers and actually sometimes welcome the standards and regulations teachers bring to Malaysia, but they do not want the added competition in being hired for teaching positions. In comparison, a country that is seen as openly welcoming Western English teachers is South Korea.

\section{South Korea}

The Republic of South Korea has only recently been put on the map as one of the most lucrative countries in the world. Aside from their exports in phones, cars, and other popular products in the global markets, the country was seen as a quiet trader and did not really get any spotlight until recently, with the political threat that is North Korea, and, on a happier note, having their entertainment industry take the world by storm in the form of South Korea's popular music commonly known as K-Pop.

Being that the country expanded so globally so fast it only seems natural that they needed to beef up the implementation of the English language in their education system. This led to the mass implementation of intensive English language curriculums in both public and private schools. Today, there are recruiting programs for western teachers that hire, place, process, and monitor the teachers once they get to South Korea. Since South Koreans do not have English as one of their native languages, or even one of their secondary languages, foreign teachers are more welcomed because of the expertise they bring with them. This gives westerners an advantage because, as they work with South Korean schools and the government, they have become more and more popular depending on their quality of work.

This also comes in contrast to the fact that learning the English language in private South Korean schools is viewed as more of a business, so foreigners teaching English is considered a source of revenue and international business all wrapped into one (Shim \& Park, 2008).

Overall, the political view in South Korea seems to be in favor of foreign teachers, especially since the English language learning has become a business that many companies are benefiting from. The government supports bringing in foreign teachers to teach English, and the people also support having foreign teachers in schools and academies to learn English (Kim \& Oh, 2012). Both sides seem to hold the view that it is to better communicate with tourists and to better compete in the international business scene.

Although English is being aggressively implemented in South Korea, the South Korean people still choose to speak in Korean first, rather than practicing a foreign language, unless they have to. The reduced strain between the people and the government on the matter, when compared to Malaysia, is mostly due to the fact that having English implemented into school systems is not seen as a threat to South Korean culture as a whole. There is no form of "westernization," like the type that is frowned upon in Malaysia, because the people have not been colonized by westerners. They maintain their culture and do not see a need to change themselves to fit western standards. To the people of South Korea, English is perceived more as a tool to be used to advance individuals and the country in the eyes of the world.

Although they are a developed nation, South Korea is relatively new in its interaction with the world in terms of international trade. But, they now use English as a tool to use in working with business partners, advancing their studies in education by going to schools in other countries, and making deals with international countries for trade. Another Asian country with similar perceptions of English to South Korea is Japan.

\section{Japan}

Japan, like South Korea, uses English as a tool to further develop and create international relationships, and like South Korea, the people of Japan also do not see English as a threat to their culture or as a form of westernization. Even so, the people of Japan are also very similar to the people of Malaysia in the sense that 
they have a strong sense of nationalism. On the spectrum of accepting and rejecting westerners to teach English, Japan is smack dab in the middle.

To shed some light on how Japan got to its middle ground, we must first take a look at its history. From the 15th to 19th centuries, Japan had an imposed policy of sakoku, or "closed country." This greatly contributed to Japan's racial, ethnic, linguistic homogeneity and cohesive national identity" (Miller, 2019). "In 1854, Japan was forced open by American military and navy to begin international trade" (Miller, 2019). This was the initial introduction of the English language and westerners into Japan.

For a country that once shunned westerners, Japan eventually embraced English as a tool to enhance their status as an international trading country (Yamagami \& Tollefson, 2010). In fact,

In East Asia, white and English-speaking migrants enjoy higher social status while the cultural or linguistic assimilation of migrants who are not English speakers is rather problematic. In this regard, the integration of these foreigners into a system of segregated but non-hierarchical multiculturalism poses a major challenge for policymaking (Kim \& Oh, 2012, p. 117).

\section{Conclusion: A Comparative Analysis}

It is already evident that creating an industry of English language teaching and learning is on the radar for South Korea, and may be starting in Malaysia as well. South Korea, however, is more open to beginning new business ventures and making strides toward global entrepreneurship. The business of hiring foreign English teachers seems to be one of the most promising new ventures. South Korea has developed programs and companies that allow teachers to enter the South Korean workforce and allows South Korean schools to employ those teachers. These companies act as go betweens or liaisons and foster the relationships that build the foreign teaching industry present in the country. South Korean recruiting groups are used to attract English teachers to South Korea, companies such as Korvia, EPIK, and Star Teachers funnel western teachers' applications into a platform where employers can then hire them. In this way, the expenses incurred by the schools during this process is profit for the recruiters. This way foreign teachers do not incur any cost other than preparing their personal files for the employers.

While Malaysia is not quite there yet, there is still time for them to develop as a country and to advance to the point where they can implement the use of western teachers similarly to the way South Korea does. It will not be so much competing with local teachers for jobs as it will be a partnership where both parties can grow and develop equally.

This leads us to the third country in this study who lies at the half-way point between South Korean teacher implementation and Malaysian teacher rejection, Japan. Like Malaysia, Japan is very nationalistic, but like South Korea, they are more willing to embrace western English teachers because they have never experienced colonization by western nations, as Malaysia has.

English is the most widely spoken language throughout the world. Each country has its own way of including English into its culture, business, and education systems. English was spread throughout the world by western civilization today's society, and that is very much still the case today. While many teachers or new graduates from western countries and universities set out to become teachers in foreign countries for various reasons, they need to be aware that not everyone will welcome a foreign teacher, even though the government might. However, one thing is clear: the teaching of English in a foreign country is more than just a linguistic issue, and these issues should be considered by teachers before pursuing this exciting international career.

\section{References}

[1] Abdullah, M.H. and Eng, W.B. (2017). Listening to the ethnic voice in ESL learning. The English Teacher, 35, 1526. 
[2] Bentley, J. (2013, August 13). 10 Reasons Why Teaching English Abroad Is The Next Step. Retrieved from https://www.studyabroad.com/resources/10-reasons-why-teaching-english-abroad-is-the-next-step

[3] Fulbright (2019). English for All Programs. Retrieved from https://exchanges.state.gov/us/english-all-programs

[4] English Program in Korea, E. (Ed.). (2019). EPIK (English program In Korea): Eligibility. Retrieved February 14, 2020, from http://www.epik.go.kr/contents.do?contentsNo=48\&menuNo=275

[5] Gray, R. (2003). Book review of McKay, S.L. (2002). Teaching English as an international language: Rethinking goals and perspectives. New York: Oxford University Press. Published in The Electronic Journal for English as a Second Language, 7(1). Retrieved online from www.tesl-ej.org/wordpress/issues/volume7/ej24/ej25r5/?wscr= on November 11, 2019.Griffin, R.W. \& Pustay, M.W. (2015). International business: A managerial perspective. Boston: Pearson.

[6] Hanapiah, M. D. (2004). English language and the language of development: A Malaysia perspective. Jurnal Kemanusiaan Universiti Teknologi Malaysia (Humanities Journal of the University of Technology of Malaysia), 2(1), 106-120.

[7] Kim, H.-R. and Oh, I. (2012). Foreigners cometh! Paths to multiculturalism in Japan, Korea and Taiwan. Asian and Pacific Migration Journal, 21(1), 105-127.

https://doi.org/10.1177/011719681202100105

[8] Manan, S.A., David, M. K., Dumanig, F. P. and Naqeebullah, K. (2015). Politics, economics and identity: Mapping the linguistic landscape of Kuala Lumpur, Malaysia. International Journal of Multilingualism, 12(1), 3150 .

https://doi.org/10.1080/14790718.2014.905581

[9] Miller, A. (2019). Lecture on Japan. PS 151: Introduction to Comparative Politics. Wilkes University, WilkesBarre, PA. November 1, 2019.

[10] Pennycook, A. (2017). The world in English. In Pennycook, A. (Ed.) (2017). The cultural politics of English as an international language. NY: Routledge.

https://doi.org/10.4324/9781315225593

[11] Shim, D. and Park, J. S.-U. (2008). The language politics of "English Fever" in South Korea. Korea Journal, 48(2),136-159.

https://doi.org/10.25024/kj.2008.48.2.136

[12] Thirusanku, J. and Yunus, M.M. (2014). Status of English in Malaysia. Asian Social Science (10)14, 254-259. https://doi.org/10.5539/ass.v10n14p254

[13] Thirusanku, J. and Yunus, M.M. (2012). The many faces of Malaysian English. International Scholarly Research Network, Volume 2012, Article ID 138928, 1-13. DOI: 10-5402/2012/138928.

[14] Tollefson, J. (2000). Policy and ideology in the spread of English. In Hall, J. K. and Eggington, W. (eds.), The Sociopolitics of English Language teaching. Clevedon: Multilingual Matters, 7-21.

[15] Yamagami, M. and Tollefson, J.W. (2010). Elite discourses of globalization in Japan: The role of English. In Yamagami, M. and Tollefson, J.W. (Eds.) (2010). English in Japan in the era of globalization. Singapore: Springer Publishing, 15-37.

https://doi.org/10.1057/9780230306196_2 